The Federal Reserve BanK of Kansas City ECONOMIC RESEARCH DEPARTMENT

Amenities, Local Conditions, and Fiscal Determinants of Factor Growth in Rural America

Eric Thompson, George Hammond, and Stephan Weiler June 2006

RWP ०6-०8 


\title{
Amenities, Local Conditions, and Fiscal Determinants of Factor Growth in Rural America
}

\author{
Eric Thompson, George Hammond, and Stephan Weiler \\ June 2006 \\ RWP 06-08
}

\begin{abstract}
This paper examines how amenities, asset indicators, and fiscal factors influence the growth in factors of production from 1972 to 1999 in the 466 non-metropolitan labor market areas in the continental United States. In developing our model of non-metropolitan factor markets, we combine the emphasis of Brown et al. (2003) on the affect of taxes and public expenditure policy on labor and capital formation with the emphasis of Beeson et al. (2001) on the importance of climate and natural features on localized population growth. We develop our own measure of capital stock in non-metropolitan areas using data from the Census of Manufacturing for 1967, 1972, 1977, 1982, 1987, and 1992. Results indicate that local taxes discourage both employment growth and manufacturing capital formation, but that local public infrastructure investment and the level of local entrepreneurship encourages employment growth. Amenities such as a favorable climate and the presence of surface water encourage the growth of employment, and greater local wealth, as measured by dividend, interest, and rent income, encourages the formation of manufacturing capital stock. Results fail to support an "export base" approach for rural economies where greater manufacturing capital stock encourages greater employment in a region.
\end{abstract}

Keywords: Regional growth, rural, manufacturing, investment, amenities, taxes, public infrastructure

JEL classification: R12, R23, R42

Economic Research Department, Federal Reserve Bank of Kansas City. Address: 925 Grand Blvd, Kansas City, MO 64198. The views expressed herein are solely those of the authors and do not necessarily reflect the views of the Federal Reserve Bank of Kansas City or of the Federal Reserve System. 


\section{Introduction}

Economic prosperity in non-metropolitan economies can be derived from a variety of sources. Among these, many non-metropolitan communities have benefited from amenity driven employment growth. Others have received substantial new investments in manufacturing as production and employment in that industry has spread from larger cities to non-metropolitan areas and selected smaller metropolitan areas. Still other areas have benefited from both approaches, given that the two strategies are far from mutually exclusive, and many of the same policies and local attributes that promote one strategy may also benefit the other.

The local attributes and policies that influence employment growth and growth in capital stock are the subject of this paper. In particular, we examine employment and manufacturing capital stock in 466 non-metropolitan labor market areas in the continental United States. The research builds on and combines recent literature that examines the importance of tax and spending policy (Brown et al., 2003) and local amenities and natural features (Beeson, et al., 2001) on sub-national economic growth. Further, while most previous studies in nonmetropolitan areas have focused on population or employment (or manufacturing employment), we also develop a measure of manufacturing capital stock by assembling county data from the Census of Manufacturing from the 1967 through 1992 period. This paper also is part of a recent literature (Weiler, 2004; Low, Henderson, and Weiler, 2005) which examines how nonmetropolitan growth is influenced by a group of Asset Indicators developed by the Center for the Study of Rural America at the Federal Reserve Bank of Kansas City.

\section{Literature Review}


A factor market model captures how factors of production such as labor and private capital stock form as a function of economic conditions, resources and fiscal policy in a local economy. Most previous studies of factor markets have examined factors of production in individual states and metropolitan areas. Crihfeld and Panggabean (1995) and Glaeser, et. al. (1995) estimated population and private capital growth in metropolitan area economies. Brown, et. al. (2003) utilized a general equilibrium model of the regional economy to derive reducedform equations for two factors of production. Brown et. al. found that public capital investment reduced growth in both private capital and labor in U.S. states. Glaeser et. al. (1995) developed a model for a single factor of production, labor.

Models of growth that have examined counties in non-metropolitan areas have focused on growth in population and employment. Among the most well-known is the model of county employment and population growth (in all U.S. counties) developed by Carlino and Mills (1987). That model utilized two-stage least squares to estimate population and employment. The model utilized regional dummies ( 9 regions of the nation) to capture how natural amenities effect growth. Many of these regional dummy variables were statistically significant in both population and employment equations. The model also examined whether selected economic attributes of each county (percent unionization, taxes per capita, family income) as well as policy variables (development bonds, interstate-highway density) were related to growth in individual counties. Among these only the highway density variable (as a measure of public capital investment), and family income were statistically significant, again both in the population and employment equations. Beeson et al. (2001) focused on population growth in all U.S. counties over the very long-run (1840 to 1990). The model considered natural amenities such as weather, topography, 
access to rivers, lakes or oceans, and manmade infrastructure such as presence of railroads and canals. All of these factors were positively correlated with long-run population growth.

The proposed model would build on Brown et al. (2003), and Glaeser et al (1995) by developing a model of local employment and capital stock for use in non-metropolitan areas. We also would build on this earlier research by combining the emphasis of Brown et al. (2003) on tax and public expenditure variables with the emphasis on local regulations, amenities, and natural features as in Carlino and Mills (1987) and Beeson et al. (2001). The proposed model also would utilize a two-stage least square approach of the type used by Carlino and Mills, rather than reduced form equations as in Beeson et al (2001) and Brown et al.(2003).

\section{Model and Data}

Building off the model of Brown et al. (2003), we develop a model with multiple factors of production. We assume a production function for firms in a sub-national region i. We assume a Cobb-Douglas form production function where output $\left(\mathrm{Q}_{\mathrm{i}}\right)$ is a function of productivity $\left(\mathrm{T}_{\mathrm{i}}\right)$, private capital $\left(\mathrm{K}_{\mathrm{i}}\right)$, and labor $\left(\mathrm{L}_{\mathrm{i}}\right)$.in region $\mathrm{i}$

$$
Q_{i}=T_{i} K_{i}^{a} L_{i}^{b}
$$

Given a regional price for private capital $\left(\mathrm{r}_{\mathrm{i}}\right)$ and labor $\left(\mathrm{w}_{\mathrm{i}}\right)$, and the price of the final $\operatorname{good}(\mathrm{P})$, the first order conditions are:

$$
L_{i}^{*}=\left[\left(P b T_{i} / w_{i}\right) K_{i}{ }^{a}\right]^{1 /(1-b)}
$$




$$
K_{i}^{*}=\left[\left(\operatorname{PaT}_{i} / r_{i}\right) L_{i}^{b}\right]^{1 /(1-a)}
$$

Following Glaeser, et. al. (1995), we assume a utility function of the following form, where $\mathrm{A}_{\mathrm{i}}$ and $\mathrm{w}_{\mathrm{i}}$ represent amenities and wages in region $\mathrm{i}$ :

$$
U_{i}=w_{i} A_{i}
$$

Given that in equilibrium utility in all regions must be equal, the following relationship would hold between any region $\mathrm{i}$ and a "composite" region US.

$$
w_{i}=w_{U S} A_{U S} / A_{i}
$$

Setting the amenity value in the composite region equal to 1 yields

$$
w_{i}=w_{U S} / A_{i}
$$

Substituting Equation 6 into Equation 2 yields:

$$
L_{i}^{*}=\left[\left(P b T_{i} A_{i} / w_{U S}\right) K_{i}^{a}\right]^{1 /(1-b)}
$$

The price of capital is set nationally ( $\mathrm{r}_{\mathrm{US}}$ ), but local conditions $(\mathrm{F})$ could lower the local cost of obtaining capital, so that $\mathrm{r}_{\mathrm{i}}=\mathrm{r}_{\mathrm{us}} / \mathrm{F}$. For example, greater wealth held by local residents could lower 
the price of risky capital since local residents may have more information about local entrepreneurs. Therefore, Equation 3 can be rewritten as:

$$
K_{i}^{*}=\left[\left(\operatorname{PaT}_{i} F_{i} / r_{U S}\right) L_{i}^{b}\right]^{1 /(1-a)}
$$

Factors that effect productivity $\left(\mathrm{T}_{\mathrm{i}}\right)$ of capital and labor in region $\mathrm{i}$ include state taxes $\left(\mathrm{ts}_{\mathrm{i}}\right)$, local taxes $\left(\mathrm{ls}_{\mathrm{i}}\right)$, public capital $\left(\mathrm{kp}_{\mathrm{i}}\right)$, regulation of the economy $\left(\mathrm{R}_{\mathrm{i}}\right)$, entrepreneurship $\left(\mathrm{EN}_{\mathrm{i}}\right)$, and highway infrastructure $\left(\mathrm{H}_{\mathrm{i}}\right)$. Amenities that influence household location choices $\left(\mathrm{A}_{\mathrm{i}}\right)$ include the mean January temperature $\left(\operatorname{Jan}_{i}\right)$, the mean July temperature $\left(\mathrm{Jul}_{\mathrm{i}}\right)$, the presence of Water $\left(\mathrm{WA}_{\mathrm{i}}\right)$, and the presence of 4-year Colleges $\left(\mathrm{C}_{\mathrm{i}}\right)$. Given this, Equation 7 can be rewritten as:

$$
L_{i}^{*}=\left[\left(P b T_{i}\left(t_{i} t_{i} k_{i} p_{i} R_{i} E N_{i} H_{i}\right) A_{i}\left(\operatorname{Jan}_{i} J u l_{i} W A_{i} C_{i}\right) / w_{U S}\right) K_{i}^{a}\right]^{1 /(1-b)}
$$

Local conditions that influence the cost of capital costs $\left(\mathrm{F}_{\mathrm{i}}\right)$ include the wealth of the local population $\left(\mathrm{WE}_{\mathrm{i}}\right)$, and the ruggedness of the terrain $\left(\mathrm{M}_{\mathrm{i}}\right)$. The ruggedness of the local terrain would influence the cost of capital investment, with a more rugged terrain raising construction costs. Since investment in buildings complements investments in other types of capital equipment, higher construction costs due to a relatively rugged terrain would raise the cost of making capital investment in the region. Equation 8 can be rewritten as:

$$
K_{i}^{*}=\left[\left(\operatorname{PaT}_{i}\left(\operatorname{ts}_{i} t l_{i} k p_{i} R_{i} E N_{i} H_{i}\right) F_{i}\left(W E_{i} M_{i}\right) / r_{U S}\right) L_{i}^{b}\right]^{1 /(1-a)}
$$


Taking the $\log$ of both sides, assuming $\mathrm{P}$ is fixed across regions, dropping both $\mathrm{P}, \mathrm{r}_{\mathrm{us}}$ and $\mathrm{w}_{\text {us }}$ since all have the same value in all regions, and assuming that $T_{i}(), A_{i}()$, and $F_{i}()$ are multiplicative functions of their explanatory variables, Equations (9) and (10) are rewritten as:

$$
\begin{aligned}
& \log \left(L_{i}^{*}\right)=b_{1}+b_{2} \log \left(K_{i}\right)+b_{3} \log \left(t s_{i}\right)+b_{4} \log \left(t l_{i}\right)+b_{t} \log \left(k p_{i}\right)+ \\
& b_{6} \log \left(R_{i}\right)+b_{7} \log \left(E N_{i}\right)+b_{8} \log \left(H_{i}\right)+b_{9} \log \left(J_{i}\right)+b_{10} \log \left(J u l_{i}\right) \\
& +b_{11} \log \left(W A_{i}\right)+b_{12} \log \left(C_{i}\right) \\
& \log \left(K_{i}^{*}\right)=b_{14}+b_{15} \log \left(L_{i}\right)+b_{16} \log \left(t s_{i}\right)+b_{17} \log \left(t l_{i}\right)+b_{18} \log \left(k p_{i}\right)+ \\
& b_{19} \log \left(R_{i}\right)+b_{20} \log \left(E N_{i}\right)+b_{21} \log \left(H_{i}\right)+b_{22} \log \left(W E_{i}\right)+b_{23} \log \left(M_{i}\right)
\end{aligned}
$$

Following Carlino and Mills (1987), we assume a partial adjustment process for both capital stock and labor.

$$
\begin{aligned}
& L_{i}=L_{i,-1}+\lambda_{L}\left(L^{*}-L_{i,-1}\right) \\
& K_{i}=K_{i,-1}+\lambda_{K}\left(K^{*}-K_{i,-1}\right)
\end{aligned}
$$

Substituting (11) and (12) into (13) and (14), the following relationships are obtained:

$$
\begin{aligned}
& \log \left(L_{i}\right)=c_{1}+c_{2} \log \left(K_{i}\right)+c_{3} \log \left(t s_{i}\right)+c_{4} \log \left(t l_{i}\right)+c_{5} \log \left(k p_{i}\right)+ \\
& c_{6} \log \left(R_{i}\right)+c_{7} \log \left(E N_{i}\right)+c_{8} \log \left(H_{i}\right)+c_{8} \log \left(\text { Jan }_{i}\right)+c_{10} \log \left(\text { Jul }_{i}\right) \\
& +c_{11} \log \left(W A_{i}\right)+c_{12} \log \left(C_{i}\right)+c_{13} \log \left(L_{i,-1}\right)
\end{aligned}
$$




$$
\begin{aligned}
& \log \left(K_{i}\right)=c_{14}+c_{15} \log \left(L_{i}\right)+c_{16} \log \left(t s_{i}\right)+c_{17} \log \left(t l_{)}\right)+c_{18} \log \left(k p_{i}\right)+ \\
& c_{19} \log \left(R_{i}\right)+c_{20} \log \left(E N_{i}\right)+c_{21} \log \left(H_{i}\right)+c_{22} \log \left(W E_{i}\right)+c_{23} \log \left(M_{i}\right) \text { (16) } \\
& +c_{24} \log \left(K_{i,-1}\right)
\end{aligned}
$$

where $c_{13}=\left(1-\lambda_{\mathrm{L}}\right)$ and $\mathrm{c}_{24}=\left(1-\lambda_{\mathrm{K}}\right)$.

\section{Estimation of the Model}

To estimate the model, employment is the measure of labor, and manufacturing capital stock is the capital stock variable. Manufacturing capital stock and non-farm employment are determined simultaneously using the approach suggested by Equations (15) and (16). Total fulland part-time employment is used rather than hours of employment since data on hours are not available in the sub-state county groups that are used in this study. We also include a set of dummy variables indicating the size code for the largest place in each labor market area. Variables are included to indicate when the largest place in the labor market area had population exceeding 20,000 (Cat3=1), and when the largest place had population between 5,000 and 20,000 (Cat2=1). The omitted category was for labor market areas where the largest place had few than 5,000. We examine data for the 1972 to 1999 period in a cross section of nonmetropolitan regions.

The model is estimated using data from 466 non-metropolitan labor market areas. These mutually exclusive and exhaustive local labor markets were developed by the U.S. Department of Agriculture's Economic Research Service to capture commuting zones in non-metropolitan as well as metropolitan areas. These ERS commuting zones are aggregations of counties, and, of the 722 LMAs in the data set, 256 are metropolitan and 466 are non-metropolitan. Metropolitan 
areas include one or more metropolitan statistical areas (MSAs) and non-metropolitan areas are those which do not contain any counties included in an MSA (Tolbert and Sizer (1996)).

Data for the labor market areas are assembled based on a county data. County data is gathered from a variety of sources and then averaged in order to obtain values for each labor market areas. In the case of categorical variables, the value is assigned based on the largest county in each labor market area. Summary statistics for the variables are reported in Table 1.

\section{Labor}

As indicated in Equation 15, employment would be a function of capital stock, production, and amenities such as average July temperature $\left(\mathrm{Jul}_{\mathrm{i}}\right)$, average January $\left(\mathrm{Jan}_{\mathrm{i}}\right)$ temperature, the percentage of county surface area that is covered by water $\left(\mathrm{WA}_{\mathrm{i}}\right)$, and the number of colleges and universities in each labor market area $\left(\mathrm{C}_{\mathrm{i}}\right)$. Values for the temperature and water amenity data are taken from the Economic Research Service. Data on the number of 4year colleges and universities in each area was assembled based on data provided by the National Center for Education Statistics, U.S. Department of Education. We utilize total full- and parttime employment in 1972 and 1999 to measure labor in the non-metropolitan economy. LMA (Li) data is summed from county total full- and part-time employment data reported in the Regional Economic Information System.

Employment would also be a function of local variables that affect the (total factor) productivity in the economy. As noted in Equation 9, local conditions that influence total factor productivity include the effective state tax rate $\left(\mathrm{ts}_{\mathrm{i}}\right)$, effective local tax rate $\left(\mathrm{tl}_{\mathrm{i}}\right)$, local public capital investment as a share of non-transfer income $\left(\mathrm{kp}_{\mathrm{i}}\right)$, regulation in the local economy $\left(\mathrm{R}_{\mathrm{i}}\right)$, the level of entrepreneurship $\left(\mathrm{EN}_{\mathrm{i}}\right)$, and highway infrastructure $\left(\mathrm{H}_{\mathrm{i}}\right)$. Regulation in the local 
economy is measured by whether the local area is in a state with a Right-to-work law. Authors such as Holmes (1998) have argued that Right-to-work laws may be reviewed as a signal of a "pro-business" environment. Data on state public capital investment is not included as there is no way to determine how much of that investment is occurring in each non-metropolitan area. Data on effective tax rates (revenue as a share of non-transfer income) come from the Census of Government. Local public capital expenditures as a share of non-transfer income are also derived from the Census of Government. We utilized 1972 data for each variable. Since state and local governments face a budget constraint, coefficients on the public capital investment variable and the tax rate variable are interpreted as relative to other public spending (Brown et al., 2003). Since we do not include a measure of state public capital investment, coefficients on effective state tax rates show how taxing to finance public spending of any kind influences growth in labor or manufacturing capital stock. Coefficients on effective local tax rates show how taxing to finance other public spending (with public capital investment held constant) influences growth in private capital and labor. Coefficients on local public capital investment show how public spending on capital investment relative to other public spending (with the tax rate held constant) effects growth in the two factors of production.

Data on entrepreneurship and highway infrastructure were available from the Asset Indicators developed by The Center for the Study of Rural America at the Federal Reserve Bank of Kansas City. The entrepreneurship breadth indicator is non-farm proprietor employment as a share of total non-farm employment. County data were aggregated to labor market area data based on each county's share of total non-farm employment in the labor market area. The highway variable is a dummy variable equal to 1 if a 4-lane interstate highway runs through one of the counties in a labor market area. 


\section{Private Capital Stock}

Private capital stock is the cumulative sum (adjusting for depreciation) of gross annual capital investment in the labor market area in each year beginning in 1957 . We utilize average annual gross investment by the manufacturing industry, and statewide capital depreciation rates for the appropriate state. Manufacturing investment is used since this data is reported for counties each 5 years in the Census of Manufacturing. We utilized data from the 1967, 1972, 1977, 1982, 1987, and 1992 Census of Manufacturing. Data from the 1997 Census of Manufacturing was not used since it was based on the NAICS industry classification system, making comparison with early data based on the SIC system difficult. Suppressed investment data in the Census of Manufacturing are allocated to counties using shares of value added. Capital expenditure for each county is assigned based on the value in the nearest Census of Manufacturing year. For example, manufacturing investment in 1968 is based on the capital investment reported in the 1967 Census of Manufacturing. County values are aggregated to labor market area values. While this study focuses on non-metropolitan areas, estimates of capital stock were calculated for all 722 labor market areas in the continental United States. For comparison, the estimated 1992 manufacturing capital stock summed across all 722 LMAs was $99 \%$ of the book value for manufacturing capital for the 48 contiguous state reported in the 1992 Census of Manufacturers.

As a measure of local wealth $\left(\mathrm{WE}_{\mathrm{i}}\right)$, we utilize per capita dividend, interest and rent income for each labor market area from 1972. We assume that the flow of income tracks the relative stock of wealth in a cross-section comparison. This measure (for the year 2003) is one of the Asset Indicators of the Center for the Study of Rural America. As noted earlier, the 
ruggedness of the local topography $\left(\mathrm{M}_{\mathrm{i}}\right)$ could influence the cost of capital investment since it raises construction costs, and since investment in buildings complements investments in other types of business capital. A region with more rugged topography may therefore have higher costs of manufacturing capital. A measure of ruggedness was developed by the Economic Research Service. All areas are rated on a scale from 1 (plains) to 21 (high mountains).

\section{Results}

Regression results based on a two-stage least squares model are illustrated in Table 2. Results are for the 466 non-metropolitan labor market areas in the contiguous 48 states. Firststage least square results are presented on the left hand side of the table and the second-stage results on the right hand side. First-stage results are largely consistent with those in the secondstage but there are several differences that point out an advantage from using a two-stage least square framework for factor markets rather than simply relying on reduced form equations alone (as in Brown et al., 2003). In the first case, the negative relationship between roughness of the topography and manufacturing capital stock is not statistically significant in the first-stage results, but the relationship is statistically significant in the second stage equation. This result may arise because rough topography, in addition to discouraging formation of manufacturing capital stock, is also an amenity that encourages larger employment, and larger employment (as seen in the second stage results) encourages formation of manufacturing capital stock. In a reduced form equation, topography has two opposing impacts on capital stock, but the negative impact on manufacturing capital stock is isolated in the second equation.

A second, related example is that the amenity variables for percentage of labor market area surface area covered in water ( pctwater $_{i}$ ) was a statistically significant determinant of the level of 
manufacturing capital stock in the reduced form equation. The second stage least squares results provide additional insight by indicating that this may be the case because the amenities encourage more employment, which was found in the second stage to encourage a larger manufacturing capital stock.

Results from the second stage equation also provide a direct assessment of the relationship between factors of production in non-metropolitan areas. Focusing on the TSLS results in Table 2, a larger manufacturing capital stock variable was not statistically significant in the employment equation. This finding fails to support an "export base" view of rural development. That view predicts that growth in exporting industries (like manufacturing) determines the overall size of the economy. ${ }^{1}$ Results, however, do support the idea growing employment leads to growth in other factors of production, including manufacturing capital. Total employment was a positive and statistically significant variable in the manufacturing capital stock equation.

Second-stage results in Table 2 also illustrate the impact of productivity variables on the two factors of production. These include taxation, public capital investment, regulation (as proxied by the presence of a Right To Work law), the level of entrepreneurship, and the presence of a 4lane interstate highway. The coefficient on the effective state tax rate variable was negative and statistically insignificant in both the employment and manufacturing capital stock equations. However, the coefficient on the effective local tax rate was negative and statistically significant. The coefficient on the local public capital investment variable was positive and statistically significant only in the employment equation. These results indicate that raising local taxes to fund other public expenditures will discourage employment and manufacturing capital stock

\footnotetext{
${ }^{1}$ The regression results do not indicate whether overall capital investment (i.e., in all industries) would increase employment growth.
} 
formation, and making public capital investments rather than making other public expenditures will encourage employment.

A Right to Work law, which was a proxy for regulation in the economy, was not found to increase the level of manufacturing capital stock or employment. The same was also true of the presence of an interstate highway in the region. The latter result is consistent with Chandra and Thompson (2000), who found that a new interstate highway did not increase aggregate labor earnings in non-metropolitan regions. The level of entrepreneurship, as measured by non-farm proprietors as a share of non-farm employment, was a positive and statistically significant variable in the employment equation.

As for factors that specifically influence employment size, three of four amenity variables were found to influence employment. Warmer January temperatures (climate amenity), cooler July temperatures and the presence of water (recreation amenity) were found to encourage more employment. The number of 4-year colleges and universities was not found to influence employment growth.

As for manufacturing capital stock, the topography variable, as a proxy for construction costs, was negative and statistically significant. The variable for per capita income from dividends, interest, and rent was positive and statistically significant in the manufacturing capital stock equation. This latter result points out the importance of maintaining wealth in nonmetropolitan areas in order encourage the formation of capital stock.

Finally, the LMA size variables (Cat 2 and Cat 3) were positive and statistically significant in the employment equation, but not in the manufacturing capital stock equation. Larger nonmetropolitan areas, which presumably have larger and more sophisticated retail and services industries, appear to have an advantage for employment growth. 


\section{Summary}

The examination of growth in 466 non-metropolitan labor market areas in the United States demonstrated that a two-stage least squares modeling approach provided a richer picture of factor growth than a reduced form approach. Further, greater employment was found to encourage the level of manufacturing capital stock but not vice versa. The latter result is at odds with export base theory, which predicts that the size of the manufacturing sector, and other "export" industries, leads overall growth in the economy.

Results further indicated that the level of local taxation discourages both employment and manufacturing capital, but that local public capital investment and greater entrepreneurship encourages employment growth. Climate and recreation amenities encouraged employment, while greater income from wealth encouraged the formation of manufacturing capital stock.

More generally, the results showed the value of developing the same types of models of factor market growth for non-metropolitan areas that are developed for states or metropolitan areas. Such models also can incorporate both the emphasis of Brown et al. (2003) on the effect of taxes and public expenditure policy on labor and capital growth with the emphasis of Beeson et al. (2001) on the importance of local climate and natural amenities on growth. There is also substantial opportunity to build on the model developed in this paper. In particular, while it may not be possible to measure capital stock across all industries, as has been done for states (Munnell, 1990; Brown et al., 2003), data are available to measure capital stock in two other "basic" industries for rural areas: agriculture and mining. 
Table 1

Summary Statistics

466 Non-Metropolitan Labor Market Areas

\begin{tabular}{|c|c|c|c|}
\hline Variable & Variable Description & Mean & $\begin{array}{l}\text { Standard } \\
\text { Deviation }\end{array}$ \\
\hline & $\begin{array}{l}1999 \text { Private Manufacturing Capital estimated based on } \\
\text { annual capital investment }(1967,1972,1977,1982,1987 \text {, }\end{array}$ & & \\
\hline PriManCap99 $\left(\mathrm{k}_{\mathrm{i}}\right)$ & 1992) (millions of 1992 Dollars) (Census of Manufacturers) & $\$ 264.34$ & $\$ 449.51$ \\
\hline & $\begin{array}{l}1969 \text { Private Manufacturing Capital estimated based on } \\
\text { annual capital investment }(1967,1972)\end{array}$ & & \\
\hline PriManCap72 $\left(\mathrm{k}_{\mathrm{i},-1}\right)$ & (millions of 1992 Dollars) (Census of Manufacturers) & $\$ 170.15$ & $\$ 339.64$ \\
\hline Emp99 $\left(L_{i}\right)$ & $\begin{array}{l}\text { Total full- and part-time employment in } 1999 \\
\text { (Regional Economic Information System) }\end{array}$ & 37,752 & 33,150 \\
\hline Emp72 $\left(\mathrm{L}_{\mathrm{i},-1}\right)$ & $\begin{array}{l}\text { Total full- and part-time employment in } 1969 \\
\text { (Regional Economic Information System) }\end{array}$ & 24,552 & 20,729 \\
\hline $\mathrm{STax} 72\left(\mathrm{ts}_{\mathrm{i}}\right)$ & $\begin{array}{l}\text { State taxes as a share of } 1972 \text { non-transfer income } \\
\text { (Census of Government) }\end{array}$ & $6.05 \%$ & $1.07 \%$ \\
\hline LTax72 $\left(\mathrm{tl}_{\mathrm{i}}\right)$ & $\begin{array}{l}\text { Local taxes as a share of } 1972 \text { non-transfer income } \\
\text { (Census of Government) }\end{array}$ & $4.41 \%$ & $1.91 \%$ \\
\hline Publnv72 (kp $\left.{ }_{\mathrm{i}}\right)$ & $\begin{array}{l}\text { Local public capital outlay as a share of non-transfer income } \\
\text { (Census of Government) }\end{array}$ & $1.32 \%$ & $1.05 \%$ \\
\hline Rtwork $\left(\mathrm{R}_{\mathrm{i}}\right)$ & $\begin{array}{l}\text { State in which LMA is centered is a Right To Work state } \\
\text { Non-farm proprietor employment as a share of non-farm } \\
\text { employment }\end{array}$ & 0.61 & 0.49 \\
\hline Entrepreneur $\left(\mathrm{EN}_{\mathrm{i}}\right)$ & (Asset Indicator of Center for the Study of Rural Development) & $21.30 \%$ & $5.73 \%$ \\
\hline Highway $\left(\mathrm{H}_{\mathrm{i}}\right)$ & $\begin{array}{l}\text { 4-Lane interstate present within labor market area (LMA) } \\
\text { (Asset Indicator of Center for the Study of Rural Development) }\end{array}$ & 0.47 & 0.50 \\
\hline Univ $\left(C_{i}\right)$ & $\begin{array}{l}\text { Number of 4-year colleges and universities in LMA } \\
\text { (National Center for Education Statistics) }\end{array}$ & 0.61 & 0.92 \\
\hline Tempjan $\left(J^{2} n_{i}\right)$ & $\begin{array}{l}\text { Mean January temperature in LMA } \\
\text { (Economic Research Service, USDA) }\end{array}$ & 29.6 & 12.2 \\
\hline Tempjul (Jul $\left.{ }_{i}\right)$ & $\begin{array}{l}\text { Mean July temperature in LMA } \\
\text { (Economic Research Service, USDA) }\end{array}$ & 74.9 & 5.8 \\
\hline Pctwater $\left(\mathrm{WA}_{\mathrm{i}}\right)$ & $\begin{array}{l}\text { Percent of LMA surface area covered by water (Economic } \\
\text { Research Service, United States Department of Agriculture) }\end{array}$ & $3.46 \%$ & $9.98 \%$ \\
\hline Topog $\left(\mathrm{M}_{\mathrm{i}}\right)$ & $\begin{array}{l}\text { Topographic scale from } 1 \text { (plains) to } 21 \text { (high mountains) } \\
\text { (Economic Research Service, USDA) }\end{array}$ & 9.66 & 6.10 \\
\hline Dirpc69 $\left(W E_{i}\right)$ & $\begin{array}{l}\text { Per capita dividend, interest, and rent income in } 1969 \\
\text { (Regional Economic Information System) }\end{array}$ & $\$ 396$ & $\$ 170$ \\
\hline Cat 2 & $\begin{array}{l}\text { Mid-Size Non-Metropolitan Region } \\
\text { (Regional Economic Information System) }\end{array}$ & 0.51 & 0.50 \\
\hline Cat 3 & $\begin{array}{l}\text { Large Non-Metropolitan Region } \\
\text { (Regional Economic Information System) }\end{array}$ & 0.23 & 0.42 \\
\hline
\end{tabular}




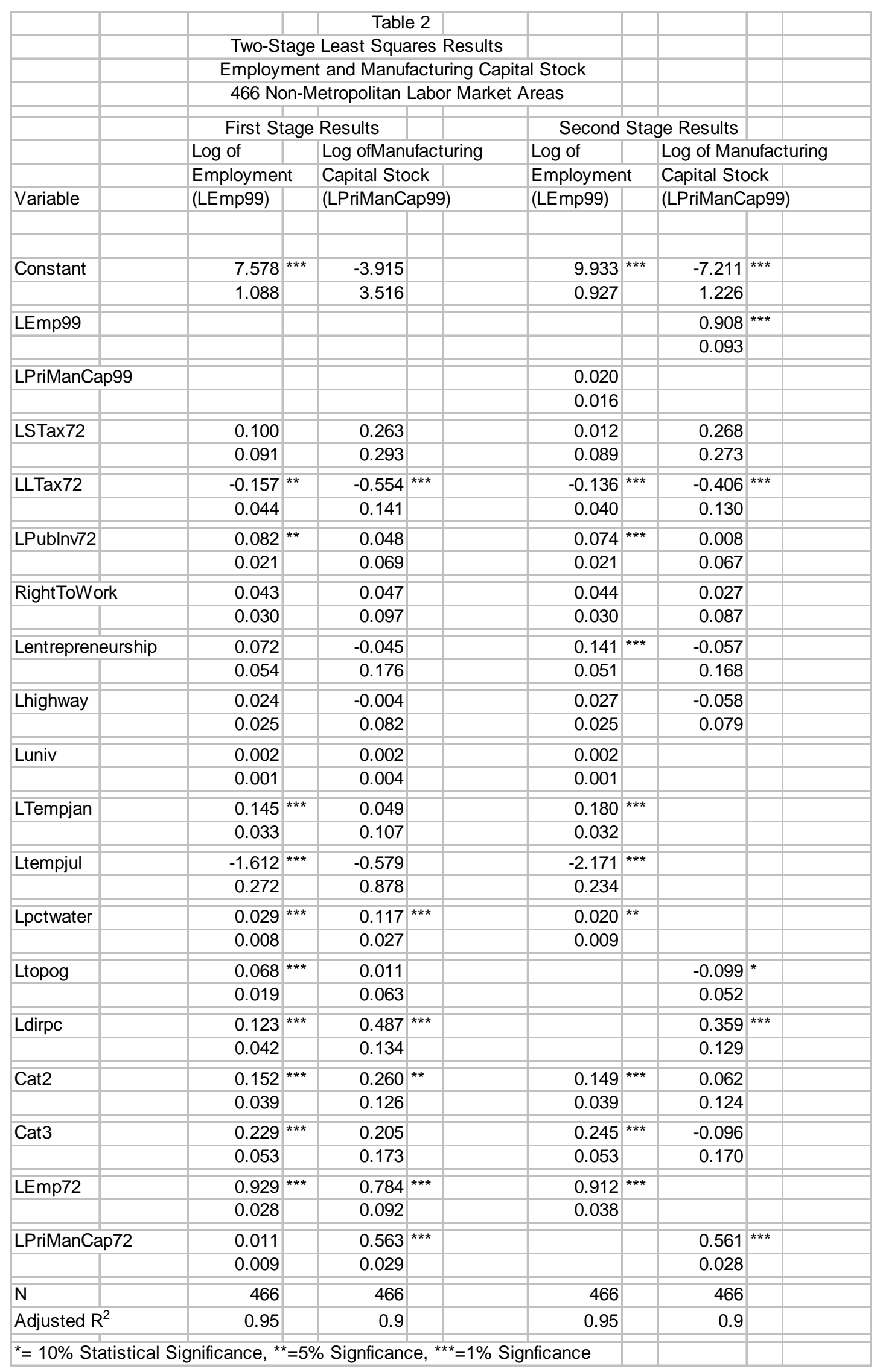




\section{References}

Beeson, Patricia E., David N. DeJong, and Werner Troesken, 2001. "Population growth in U.S. Counties, 1840-1990," Regional Science and Urban Economics 31: 669-699.

Brown, Stephen P.A., Kathy J. Hayes, and Lori L. Taylor, 2003. "State and Local Policy, Factor Markets, and Regional Growth," The Review of Regional Studies. 33 (1): 40-60.

Carlino, Gerald A., and Edwin S. Mills, 1987. "The Determinants of County Growth," Journal of Regional Science. 37(1): 39-54.

Chandra, Amitabh, and Eric Thompson, 2000. "Does public infrastructure affect economic activity?

Evidence from the rural interstate highway system," Regional Science and Urban Economics. 30: 457-490.

Crihfield, John B., and Martin P.H. Panggabean, 1995. "Growth and Convergence in U.S. Cities," Journal of Urban Economics. 38: 138-165.

Glaeser, Ed and Jose A. Scheinkman, and Andrei Shleifer, 1995. "Economic growth in a cross-section of cities," Journal of Monetary Economics 36: 117-143.

Hammond, George, and Eric Thompson, 2005. "Convergence and Growth in U.S. Metropolitan and Nonmetropolitan Labor Markets," Unpublished manuscript.

Holmes, Thomas J., 1998. "The Effect of State Policies on the Location of Manufacturing: Evidence from State Borders," Journal of Political Economy. 106(4): 667-705.

Low, Sarah, Jason Henderson, and Stephan Weiler, 2005. "Gauging a Region's Entrepreneurial Potential," Economic Review. (Third Quarter). Federal Reserve Bank of Kansas City.

Munnell, Alicia H., 1990. "Why Has Productivity Growth Declined? Productivity and Public Investment," New England Economic Review. (Jan/Feb). Federal Reserve Bank of Boston.

Tolbert, Charles M. and Molly Sizer, 1996. "U.S. Commuting Zones and Labor Market Areas: A 1990 Updated," ERS Staff Paper \#9614, Economic Research Service, Rural Economy Division.

Weiler, Stephan, 2004. "Racing Towards New Frontiers: Helping Regions Compete in the Global Marketplace." The Main Street Economist, March. 